\title{
COST-EFFECTIVE THERMAL-INSULATING BUILDING MATERIALS
}

\author{
CENENI IN UČINKOVITI TOPLOTNO IZOLATIVNI GRADBENI \\ MATERIALI
}

\author{
Salvador Noriega Morales', Adán Valles Chávez², Vianey Torres-Argüelles ${ }^{1 *}$, \\ Mario Castillo Venegas ${ }^{2}$, Andrés Hernández Gómez ${ }^{1}$, Daniel Alaniz-Lumbreras ${ }^{3}$, \\ Victor Castaño Meneses ${ }^{4}$ \\ ${ }^{1}$ Department of Industrial and Manufacturing Engineering, Institute of Engineering and Technology, Autonomous University of Ciudad Juárez, \\ Av. Del Charro 450 N, Ciudad Juárez, Chih., México \\ 2Division of Graduate Studies and Research, Technological Institute of Ciudad Juárez, Av. Tecnológico No. 1340, \\ Ciudad Juárez, Chih., México \\ ${ }^{3}$ Engineering Electric Faculty, Autonomous University of Zacatecas, Carretera a la Bufa, 98000 Zacatecas, Zac., México \\ ${ }^{4}$ Center for Applied Physics and Advanced Technology, Autonomous University of Ciudad Juárez, Av. Del Charro $450 \mathrm{~N}$, \\ Ciudad Juárez, Chih., México \\ Prejem rokopisa - received: 2019-05-14; sprejem za objavo - accepted for publication: 2020-03-29
}

doi:10.17222/mit.2019.100

\begin{abstract}
We report on the development of a formula for an adequate mix of aggregates to produce concrete blocks, which, while preserving high mechanical resistance, show good thermal insulation and reduced production costs. Three aggregates with different proportions were compared, consisting of pumice, wood shavings and basalt; the amounts of each material were 1800 , 1970 and $2150 \mathrm{~kg}$. A three-factor experimental design was applied to statistically determine the best factors for the response variables, namely, a high compression resistance and low thermal conductivity. The best mix obtained is composed of $250 \mathrm{~kg}$ of cement, $1970 \mathrm{~kg}$ of pumice and three amounts of sand with minor differences.

Keywords: thermal conductivity, thermal resistance, concrete block, aggregates
\end{abstract}

Avtorji poročajo o razvoju formule primerne za proizvodnjo betonskih blokov iz mešanice agregatov. Izdelani betonski bloki so poceni in imajo dobre mehanske ter termične izolativne lastnosti. Med seboj so primerjali tri vrste agregatov (lehnjak, lesne ostružke in bazalt), v različnih deležih, vsakega po (1800, 1970 in 2150) kg. Izvedli so trofaktorski eksperimentalni dizajn, da bi lahko statistično ovrednotili najboljše faktorje za izbrani optimalni vrednosti obeh spremenljivk; ti sta: najvišja tlačna trdnost in najnižja toplotna prevodnost. Na osnovi analize so ugotovili, da je najboljša mešanica sestavljena iz $250 \mathrm{~kg}$ cementa in $1970 \mathrm{~kg}$ lehnjaka. Pri tem pa so minimalne razlike v izbranih deležih peska (bazalta).

Ključne besede: toplotna prevodnost, termična upornost, betonski blok, izolacijski materiali

\section{INTRODUCTION}

It is well known that the average temperature on the planet surface is rising. Indeed, between 1901 and 2012, the global average surface temperature increased by about $0.89^{\circ} \mathrm{C},{ }^{1}$ and it is projected to rise by an additional $1.4{ }^{\circ} \mathrm{C}$ to $5.8{ }^{\circ} \mathrm{C}$ over the 21 st century; this increase mainly depends on the emission trends of the greenhouse gases. $^{2-4}$ These changes in the temperature are occurring worldwide and they also affect regional weather because the heat in the atmosphere drives the climate system. ${ }^{5}$ In the desert and high desert regions of the northern hemisphere, winters are cold and summers are hot. In such climates, the extreme temperatures, fluctuating in a range of $-10-40{ }^{\circ} \mathrm{C}$, increase the demand for thermal comfort, which brings, in turn, an increase in the energy consumption for heating, ventilation and air-conditioning systems. Therefore, there is a growing concern about the energy consumption in buildings needed for air condi-

*Corresponding author's e-mail:

vianey.torres@uacj.mx (Vianey Torres-Argüelles) tioning and the likely adverse impacts on the environment. ${ }^{6,7}$ In 2018, the U.S. Energy Information Administration reported a production of $106,877.162 \mathrm{PJ}$, and a consumption of 7,279.88 PJ only by the building sector in this country. ${ }^{8}$ While in Mexico, in 2017, the consumption of the residential, commercial and public sectors was 74.89 GJ per capita, i.e., 5,498.89 PJ, of which $944.09 \mathrm{PJ}$ was the consumption only in the residential sector. ${ }^{9}$

Nowadays, the International Energy Agency ${ }^{10}$ is focusing on the efficient use of energy. In fact, buildings currently use up to $40 \%$ of the primary energy consumption in most countries. ${ }^{11-13}$ Also, $79 \%$ of the world energy consumption comes from fossil fuel, which is a finite and non-renewable source. ${ }^{14}$ Therefore, in recent years, both energy and environment have become high-priority areas for the developed and developing countries. The United Nations Industrial Development Organization promotes energy efficiency, with the aim of mitigating climate change and making industry environmentally sustainable. ${ }^{15}$ Nevertheless, the economic/in- 
dustrial development and population boom in the last few centuries resulted in a huge increase in the energy demand with an annual incremental trend of about $2.3 \% .{ }^{16}$ An alternative to reduce the energy consumption is the use of building envelopes. However, the use of building envelopes increases the thickness of the walls and requires a higher cost.

Hence, another possible alternative to reduce this high energy demand is the use of thermal building materials. ${ }^{17}$ Generally speaking, the main properties of a thermal material is a low thermal conductivity and high thermal resistance. The thermal conductivity $(\lambda)$ is one characteristic of concrete that can be changed when combined with other materials. It is defined as the quantity of the heat transmitted through a thickness unit in the direction normal to the surface of the unit area due to the unit temperature gradient under steady state conditions. ${ }^{18}$ The thermal resistance of building materials is an important property while defining the total energy consumption of heating and cooling systems and achieving the optimal thermal comfort for the occupants. ${ }^{19,20}$ Meanwhile, the thermal resistance is proportional to the thickness of a layer of the construction and inversely proportional to its conductivity: ${ }^{21}$

$$
R=\frac{e}{\lambda}
$$

where $e$ is the thickness of the layer $(\mathrm{m})$ and $\lambda$ is the thermal conductivity $\left(\mathrm{W} \mathrm{m} \mathrm{m}^{-1} \mathrm{~K}^{-1}\right)$.

The combined impact of the climate variables, such as the temperature, solar irradiation, wind and humidity on the energy balance of a building depends on the characteristics of the building, such as its design, orientation, mode of operation, maintenance, and construction materials. Concrete is the most widely used material in the world with an annual consumption of around five billion tons, ${ }^{22}$ and the most used material in the construction industry is a concrete block, although its highest quality leads to higher housing prices, even more so when the heating and cooling costs are taken into account. Therefore, it is very important to develop better thermal qualities of concrete blocks, searching for adequate materials and the best mix for the improvement of the thermal insulation and acceptable strength.

Cement is the binding phase in concrete and it usually constitutes about 15-25\% of the concrete weight, ${ }^{22}$ while the aggregates can constitute between $70 \%$ and $80 \%$. One of the means to increase the efficiency of energy consumption in the case of building materials and, specifically, blocks of concrete, is based on the reduction of the cement percentage $e^{23}$ as well as adding other materials, which may result in improved properties, such as the thermal resistance and compressive resistance. ${ }^{24}$ The common aggregates for the reinforced concrete are plastics, clays, volcanic slag like basalt and pumice stone, rubber, cork and wood. Furthermore, one of the effects of swelling clay additions to concretes is an increase in the compressive yield stresses..$^{25}$

Basalt is the most frequent rock in the earth crust. It has a vesicular texture, with traces of the bubbles produced by water vapor during the cooling of lava. Basalt is an inert, naturally occurring volcanic rock, with advantages in terms of $\cos ^{26}$ and because it can be aggregated without other additives. In addition, it is well known that less energy is needed for the production because of its production simplicity. Also, adding basalt to concrete increases the critical compressive strain and, consequently, the deformation capacity of geopolymer concrete can notably be improved. ${ }^{27}$ Regarding wood shavings, they are easily acquirable, low-priced and renewable. When wood is added to concrete, a stable, compact, resistant and durable structure is obtained; at the same time, the alveolar structure causes a good thermal behavior and lowers the weight. ${ }^{28}$ It exhibits an unlimited durability, without a chemical or biological degradation, and this is why it is considered one of the best ecological materials. Pumice stone is a natural material of volcanic origin; it is light and resistant; due to its properties, it helps to reduce the weight of concrete. $^{29}$

This paper reports about a search for a formulation of a cost-effective mixture of materials, including three aggregates, for the production of concrete blocks with a high compressive resistance and low thermal conductivity. This is very important because the sustainable world's economic growth greatly depends on the use of new products in the construction industry.

\section{MATERIALS AND METHODS}

The manufacturing technology for concrete blocks is based on the Mexican Official Norms NMX-C-404ONNCCE-2005 and NMX-C-441-ONNCCE-2005, ${ }^{30,31}$ which have equivalents in other countries, specifically in the US and Europe. By definition, a concrete block is a prefabricated concrete piece, prism-shaped and with one or more vertical openings; it is used in masonry systems or simple structures, which opens the possibility of having strengthening pieces in both directions of its plane. ${ }^{30}$ According to the Mexican Official Norm NMX$\mathrm{C}-038,{ }^{32}$ for manufacturing concrete blocks, the thickness of each block must be at least $15 \mathrm{~mm}^{2}$ and the dimensions of the blocks are $(20 \times 20 \times 40) \mathrm{cm}$, based on the standard NMX-C-441-ONNCCE-2005. ${ }^{32}$ Also, the compressive resistance was based on the standard NMX-C-036, ${ }^{33}$ and the standard values are $40 \mathrm{~kg} \mathrm{f} \mathrm{cm}^{-2}$ for the standard line and $60 \mathrm{~kg} \mathrm{f} \mathrm{cm}{ }^{-2}$ for the structural line.

In general, the properties of concrete are mainly determined by the quality of aggregates as they are the major constituents of concrete, typically occupying between $60 \%$ and $80 \%$ of the concrete volume. ${ }^{34,35}$ The materials used in this study include ordinary Portland 
cement complying with the ASTM Type I standards, at an average percentage of $8.8 \%$, sand at an average percentage of $22 \%$, and the studied aggregates including pumice, basalt and wood shavings at an average percentage of $69 \%{ }^{36}$

The block production process consists of vibration/ compression of the mix, together with a conveyor feed of the materials into a mold, vibration and compression to displace air and enhance cohesion. After that, the blocks are placed in a cure chamber with controlled water vapor to obtain ready-to-use high-quality blocks within $24 \mathrm{~h}$. The process involves molding in a Besser machine block, model Dynapac. The measured variables were: the thermal conductivity ( $\mathrm{R}$ factor), compressive resistance and total thermal resistance $\left(R_{\mathrm{T}}\right)$. The thermal conductivity was obtained through the Netzsch equipment, model 2300 Lambda, which measures the heat flow in $\mathrm{W} \mathrm{m}^{-1} \mathrm{~K}^{-1}$. The compressive resistance was measured based on the ASTM C 31, C 39, C 617, C 1077 and C 1231 norms,${ }^{36}$ which are applied when testing the compressive resistance of concrete. Finally, the total thermal resistance is the sum of the partial thermal resistances and was obtained with Equation (2), which is based on Equation (1).

$$
\begin{aligned}
& R_{\mathrm{T}}=r_{s i}+R_{1}+R_{2}+R_{3}+r_{s e}= \\
& =\frac{1}{h_{i}}+\frac{L}{\lambda_{1}}+\frac{L}{\lambda_{2}}+\frac{L}{\lambda_{n}}+\frac{1}{h_{e}}
\end{aligned}
$$

Here, $L$ is the thickness of the material layer of the component $(\mathrm{m}) ; \lambda$ is the thermal conductivity of the material obtained with measurements $\left(\mathrm{W} \mathrm{m}^{-1} \mathrm{~K}^{-1}\right)$; $\mathrm{h}_{\mathrm{i}}$ is the conductance in the inner surface $\left(\mathrm{W} \mathrm{m}^{-1} \mathrm{~K}^{-1}\right)$, the value used in this study was $8.1 \mathrm{~W} \mathrm{~m}^{-1} \mathrm{~K}^{-1}$ based on the standard NOM-008-ENER-2001;37 $h_{\mathrm{e}}$ is the conductance is the external surface $\left(\mathrm{W} \mathrm{m}^{-1} \mathrm{~K}^{-1}\right)$ and its standard value is $13 \mathrm{~W} \mathrm{~m}^{-1} \mathrm{~K}^{-1} ; \mathrm{n}$ is the number of terms of the evolving portion. Figure 1 presents a schematic representation of the partial compressive resistance.

\subsection{Experimental set-up}

The experimental work was performed based on a mixed factorial design of experiments. Three factors were selected: cement content, sand content, and the content of aggregates. For the first factor, we assigned two levels, $250 \mathrm{~kg}$ and $300 \mathrm{~kg}$ of cement. For the second and third factor, we assigned three levels, (550, 630 and $710) \mathrm{kg}$ of sand, and (1800, 1970 and 2150) $\mathrm{kg}$ for each aggregate. Thirty-six samples were analysed and the

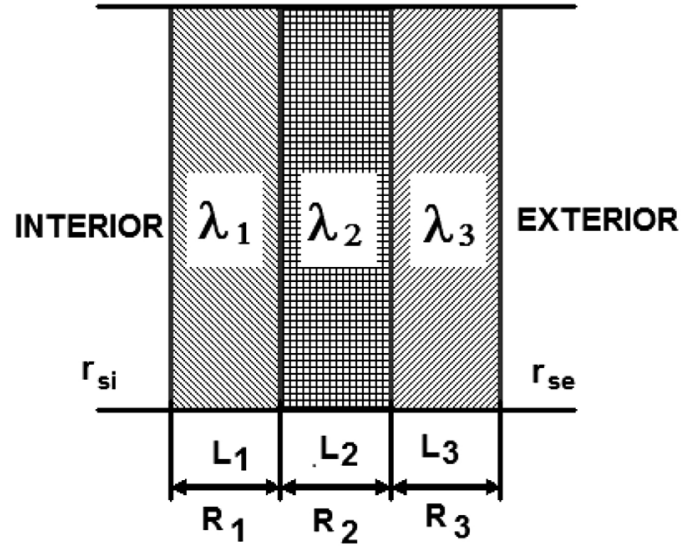

Figure 1: Schematic representation of the partial compressive resistance

resistance was measured for the blocks made of different mixtures of aggregates, obtaining twelve values for each aggregate: six values for the combination of cement, sand and aggregate, and two values for each combination of aggregate and sand.

\subsection{Statistical analysis}

A statistical analysis was performed using a Student's t-test and ANOVA. The former is used to compare the results of the mean compressive resistance for each aggregate, considering the levels of the sand and cement contents. Additionally, in order to determine if there is a significant difference in the average compressive resistance between the aggregates, a statistical analysis was applied involving an analysis of variance (ANOVA), using the SPSS statistical software, version $17 .{ }^{38}$

\section{RESULTS AND DISCUSSION}

This section presents the findings of the study. Table 1 shows the results obtained with the study and we can see in the second column that the thermal conductivity is lower than the standard value for concrete, with values of $0.265 \mathrm{~W} \mathrm{~m}^{-2} \mathrm{~K}^{-1}$ for pumice, $0.274 \mathrm{~W} \mathrm{~m}^{-2} \mathrm{~K}^{-1}$ for basalt and $0.229 \mathrm{~W} \mathrm{~m}^{-2} \mathrm{~K}^{-1}$ for wood shavings. When compared to the standard value obtained for the concrete without an aggregate, there are differences of (37, 35 and 45) $\%$, respectively, given that according to F. M. Díez Ramírez et al. ${ }^{21}$ the coefficient of thermal conductivity of dry concrete fluctuates in a range of $0.09-2.30 \mathrm{~W} \mathrm{~m}^{-2} \mathrm{~K}^{-1}$, and depends on the type of aggregate, its composition and air content. In the case of this study, the standard

Table 1: Thermal conductivity, thermal resistance, total thermal resistance and mean compressive resistance for each aggregate

\begin{tabular}{|c|c|c|c|c|}
\hline Material & $\begin{array}{c}\text { Thermal conductivity } \\
\left(\mathrm{W} \mathrm{m} \mathrm{K}^{-1}\right)\end{array}$ & $\begin{array}{c}\text { Thermal resistance } \\
\left(\mathrm{m}^{2} \mathrm{~K} \mathrm{~W}^{-1}\right)\end{array}$ & $\begin{array}{c}\text { Total thermal resistance } \\
\left(\mathrm{m}^{2} \mathrm{~K} \mathrm{~W}^{-1}\right)\end{array}$ & $\begin{array}{c}\text { Mean compressive } \\
\text { resistance }\left(\mathrm{kg} \mathrm{f} \mathrm{cm}^{-2}\right)\end{array}$ \\
\hline Pumice & 0.265 & 0.755 & 1.036 & 57.50 \\
\hline Basalt & 0.274 & 0.730 & 1.011 & 56.00 \\
\hline Wood shavings & 0.229 & 0.875 & 0.400 & 46.00 \\
\hline Concrete & 0.420 & 0.390 & 40.00 \\
\hline
\end{tabular}



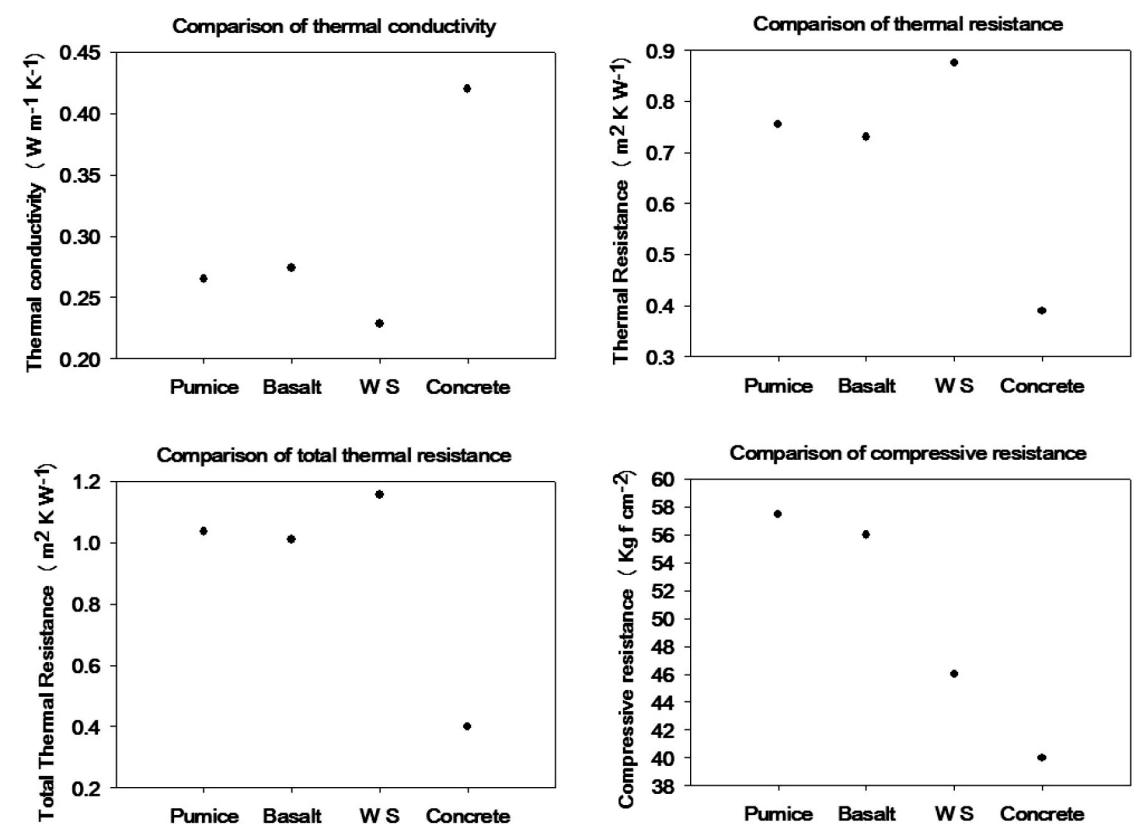

Figure 2: Comparison of the results for pumice, basalt, wood shavings (ws) and concrete, for four measured variables: a) thermal conductivity, b) thermal resistance, c) total thermal resistance, and d) mean compressive resistance

Table 2: Descriptive statistics for block compressive resistance: mean, standard deviation, minimum and maximum values

\begin{tabular}{|c|c|c|c|c|c|c|c|c|c|c|}
\hline \multirow{2}{*}{$\begin{array}{c}\text { Cement } \\
(\mathrm{kg})\end{array}$} & \multirow{2}{*}{$\begin{array}{c}\text { Sand } \\
(\mathrm{kg})\end{array}$} & \multicolumn{3}{|c|}{ Pumice (kg) } & \multicolumn{3}{|c|}{ Basalt (kg) } & \multicolumn{3}{|c|}{ Wood shavings (kg) } \\
\hline & & 1800 & 1970 & 2150 & 1800 & 1970 & 2150 & 1800 & 1970 & 2150 \\
\hline \multirow{6}{*}{250} & \multirow{2}{*}{550} & 37 & 38 & 25 & 39 & 32 & 22 & 28 & 29 & 19 \\
\hline & & 33 & 39 & 28 & 35 & 32 & 29 & 25 & 24 & 22 \\
\hline & \multirow{2}{*}{630} & 46 & 39 & 44 & 42 & 35 & 46 & 33 & 23 & 38 \\
\hline & & 42 & 44 & 47 & 46 & 47 & 43 & 38 & 31 & 38 \\
\hline & \multirow{2}{*}{710} & 36 & 50 & 34 & 38 & 53 & 37 & 25 & 47 & 22 \\
\hline & & 37 & 52 & 33 & 39 & 56 & 36 & 21 & 40 & 20 \\
\hline \multirow{6}{*}{300} & \multirow{2}{*}{550} & 57 & 51 & 51 & 55 & 55 & 49 & 52 & 45 & 39 \\
\hline & & 56 & 56 & 46 & 56 & 53 & 47 & 50 & 47 & 34 \\
\hline & \multirow{2}{*}{630} & 54 & 58 & 50 & 56 & 57 & 52 & 41 & 45 & 45 \\
\hline & & 51 & 57 & 49 & 52 & 55 & 46 & 43 & 47 & 46 \\
\hline & \multirow{2}{*}{710} & 54 & 51 & 42 & 55 & 54 & 39 & 46 & 45 & 31 \\
\hline & & 57 & 54 & 46 & 59 & 57 & 41 & 51 & 42 & 39 \\
\hline Mean & & 46.67 & 49.08 & 41.25 & 47.67 & 48.83 & 40.58 & 37.75 & 38.75 & 32.75 \\
\hline $\mathrm{Sd}$ & & 9.23 & 7.28 & 8.94 & 8.70 & 9.93 & 8.65 & 11.11 & 9.31 & 9.75 \\
\hline Min & & 33 & 38 & 25 & 35 & 32 & 22 & 21 & 23 & 19 \\
\hline Max & & 57 & 58 & 51 & 59 & 57 & 52 & 52 & 47 & 46 \\
\hline
\end{tabular}

value of the concrete was $0.42 \mathrm{~W} \mathrm{~m}^{-2} \mathrm{~K}^{-1}$. These results are better than the ones reported by L. Gündüz, ${ }^{39}$ who says that by adding pumice to a mix of cement and aggregate, a thermal conductivity of $0.34 \mathrm{~W} \mathrm{~m}^{-2} \mathrm{~K}^{-1}$ was obtained. In addition, our results are better than the ones from S. A. Marcott et al. ${ }^{4}$ who reported a mean thermal conductivity of $1.25 \mathrm{~W} \mathrm{~m}^{-2} \mathrm{~K}^{-1}$.

According to the results, in the case of the thermal resistance, the difference is significant and represents an increase of $93.6 \%$ for pumice, $87.1 \%$ for basalt and 124 $\%$ for wood shavings, in relation to the concrete standard value. At the same time, the mean compressive resistance measured for the blocks with added materials shows an important increase of $(43.75,40$ and 15) \% for pumice, basalt and wood shavings, respectively. The mix with pumice exhibits the best properties among the studied mixes. The results described are presented in Figure 2, which also gives the differences in the behaviour of the variables measured for the blocks with the concrete mix, sand and aggregates, in relation to the standard values for concrete blocks.

As mentioned above, the average percentages of the contents of the materials used are $8.8 \%$ for cement, $22 \%$ for sand and $69 \%$ for the aggregates for each formula. Table 2 shows the calculated compressive resistance. The minimum compressive strength was $19 \mathrm{~kg} \mathrm{f} \mathrm{cm}-2$, obtained by mixing $250 \mathrm{~kg}$ of cement, 550 $\mathrm{kg}$ of sand and $2150 \mathrm{~kg}$ of wood shavings. The maxi- 

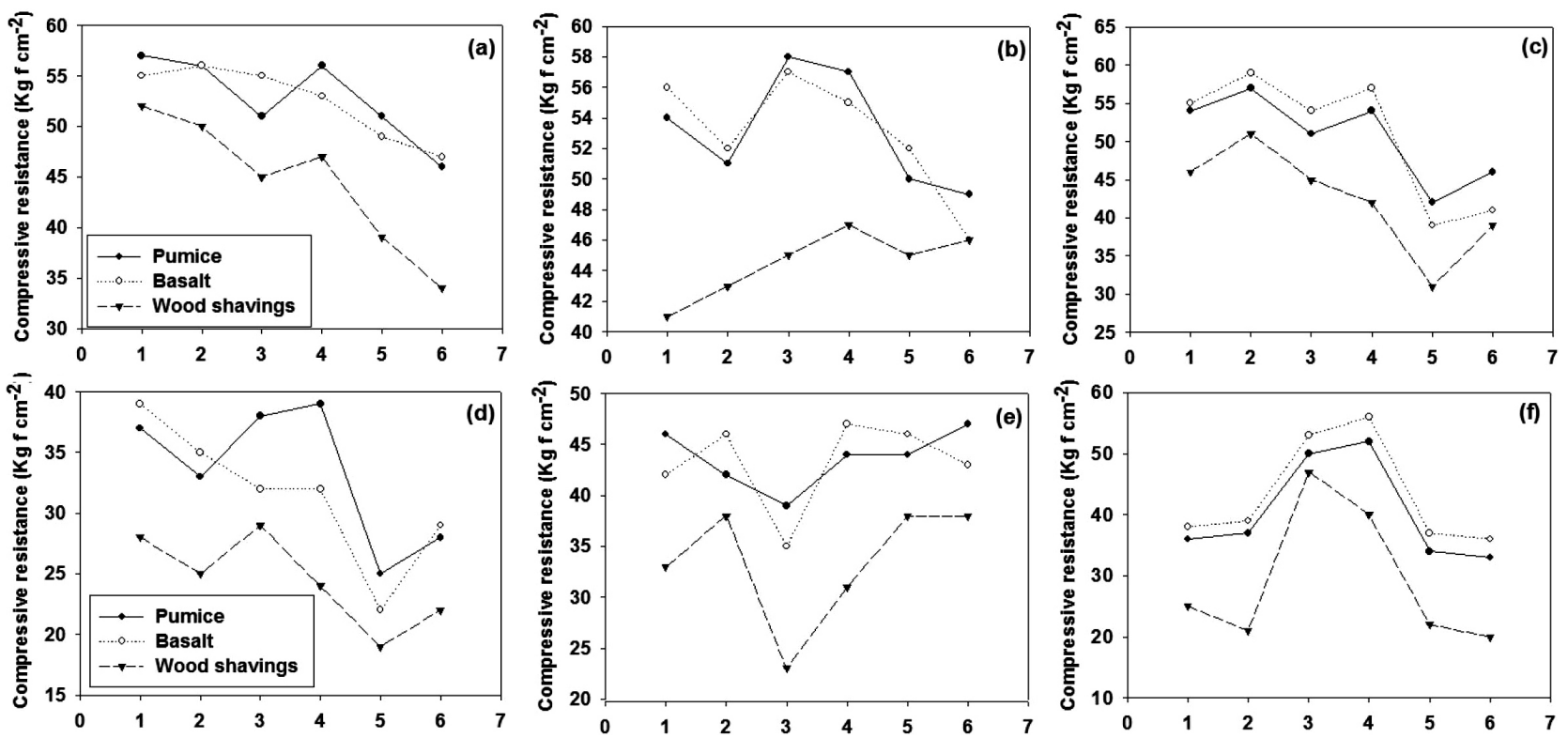

Figure 3: Comparison of the values for the total compressive resistance for three aggregates with three different levels of sand and two different levels of cement: a) 550 , b) 630 , c) $710 \mathrm{~kg}$ of sand for $250 \mathrm{~kg}$ of cement; d) 550 , e) 630 , f) $710 \mathrm{~kg}$ of sand for $300 \mathrm{~kg}$ of cement

Table 3: ANOVA of the compressive resistance

\begin{tabular}{|c|c|c|c|c|c|}
\hline \multicolumn{5}{|c|}{ ANOVA aggregates } \\
\hline & Sum of squares & df & Mean square & F & 4.621 \\
\hline Between groups & 3172.241 & 8 & 396.530 & .000 \\
\hline Within groups & 8495.833 & 99 & 85.816 & & \\
\hline Total & 11668.074 & 107 & & \\
\hline
\end{tabular}

mum compressive strength was $59 \mathrm{~kg} \mathrm{f} \mathrm{cm} \mathrm{cm}^{-2}$, obtained by mixing $300 \mathrm{~kg}$ cement, $710 \mathrm{~kg}$ of sand and $1800 \mathrm{~kg}$ of basalt. According to the average and standard deviation values of $49.08 \mathrm{~kg} \mathrm{f} \mathrm{cm}^{-2}$ and $7.28 \mathrm{~kg} \mathrm{f} \mathrm{cm}^{-2}$, respectively, the best mixture was obtained by adding $1970 \mathrm{~kg}$ of pumice. The lower mean value of compressive strength was obtained by adding wood shavings, the value being 32.75 . However, with this material, we obtained a lower thermal conductivity and higher thermal resistance. Our results are similar to those reported by D. K. Panesar and B. Shindman ${ }^{40}$ who obtained a compressive resistance of $79.5 \mathrm{~kg} \mathrm{f} \mathrm{cm}^{-2}$, after 28 days of drying, of a mixture of $10 \%$ CSandBlend $+10 \%$ CStoneBlend and $80 \%$ Portland cement. It is noteworthy that our blends contain only $9 \%$ of cement and $22 \%$ of sand. In our study, the aggregate predominates in the mixture with $69 \%$.

F. Pelisser et al. ${ }^{23}$ combined cement and rubber, adding $40 \%$ of this aggregate; the average thermal conductivity was 0.737 and the thermal resistance was 0.306 . In the case of the thermal conductivity, our results are, on average, by $65 \%$ lower, and in the case of the thermal resistance, our results are better by more than $100 \%$. Figure 3 shows the behaviour of the compressive strength obtained with mixtures of different aggregates. We can see that, in all the cases, the compressive strength of different mixtures containing wood chips is lower than that of the mixtures containing pumice and basalt. Also, the pumice and basalt mixes show similar behaviours at all levels, including the mixes of $250 \mathrm{~kg}$ of cement, $630 \mathrm{~kg}$ and $710 \mathrm{~kg}$ of sand, and the mix of $300 \mathrm{~kg}$ of cement with $710 \mathrm{~kg}$ of sand.

\section{STATISTICAL ANALYSIS}

Table 3 reports the results of ANOVA. It indicates statistically significant differences between the results for the three aggregates. For this purpose, Student's t-test was used. Table 4 shows significant differences between the three levels of each aggregate. The statistically significant differences were found in the case of the highest level, i.e., $2150 \mathrm{~kg}$ of both pumice and basalt, compared to the other two levels, 1800 and $1970 \mathrm{~kg}$, except for the comparison between 1970 and $2150 \mathrm{~kg}$ of wood shavings. At the same time, Table $\mathbf{5}$ shows Student's t-test for the three levels of the aggregates. In this case, significant differences observed between the mixtures containing wood chips and those containing pumice and basalt, have a .000 P-value for the three levels of the aggregate material studied. On the other hand, the results obtained for the mixtures containing pumice and basalt show no statistically significant differences.

The materials proposed in this study performed better than those reported by $\mathrm{O}$. Ünal et al. ${ }^{41}$ who used dio- 


\section{SALVADOR NORIEGA et al.: COST-EFFECTIVE THERMAL-INSULATING BUILDING MATERIALS}

Table 4: Student's t-test of the compressive resistance at three levels of each aggregate

\begin{tabular}{|c|c|c|c|c|c|c|c|c|c|}
\hline & & \multicolumn{5}{|c|}{ Paired differences } & \multirow{3}{*}{$\mathrm{t}$} & \multirow{3}{*}{ df } & \multirow{3}{*}{$\begin{array}{c}\text { Sig. } \\
\text { (2-tailed) }\end{array}$} \\
\hline & & \multirow[b]{2}{*}{ Mean } & \multirow[b]{2}{*}{$\begin{array}{c}\text { Std. } \\
\text { deviation }\end{array}$} & \multirow[b]{2}{*}{$\begin{array}{c}\text { Std. error } \\
\text { mean }\end{array}$} & \multicolumn{2}{|c|}{$\begin{array}{l}95 \% \text { confidence interval } \\
\text { of the difference }\end{array}$} & & & \\
\hline & & & & & Lower & Upper & & & \\
\hline Pair 1 & P_1800 - P_1970 & -2.42 & 7.05 & 2.04 & -6.90 & 2.06 & -1.18 & 11 & .260 \\
\hline Pair 2 & P_1800-P_2150 & 5.42 & 5.11 & 1.47 & 2.17 & 8.66 & 3.67 & 11 & .004 \\
\hline Pair 3 & P_1970 - P_2150 & 7.83 & 7.25 & 2.09 & 3.23 & 12.44 & 3.74 & 11 & .003 \\
\hline Pair 4 & B_1800-B_1970 & -1.17 & 7.57 & 2.18 & -5.97 & 3.64 & -0.53 & 11 & .604 \\
\hline Pair 5 & B_1800-B_2150 & 7.08 & 6.79 & 1.96 & 2.77 & 11.40 & 3.62 & 11 & .004 \\
\hline Pair 6 & B_1970-B_2150 & 8.25 & 8.23 & 2.37 & 3.02 & 13.48 & 3.47 & 11 & .005 \\
\hline Pair 7 & WS_1800 - WS_1970 & -1.00 & 10.25 & 2.96 & -7.51 & 5.51 & -0.34 & 11 & .742 \\
\hline Pair 8 & WS_1800 - WS_2150 & 5.00 & 7.65 & 2.21 & 0.14 & 9.86 & 2.26 & 11 & .045 \\
\hline Pair 9 & WS_1970 - WS_2150 & 6.00 & 11.21 & 3.24 & -1.12 & 13.12 & 1.85 & 11 & .091 \\
\hline
\end{tabular}

Table 5: Student t-test for the compressive resistance between three agreggates

\begin{tabular}{|c|c|c|c|c|c|c|c|c|c|}
\hline & & \multicolumn{5}{|c|}{ Paired differences } & \multirow{3}{*}{$\mathrm{t}$} & \multirow{3}{*}{ df } & \multirow{3}{*}{$\begin{array}{c}\text { Sig. } \\
(2-\text { tailed })\end{array}$} \\
\hline & & \multirow[b]{2}{*}{ Mean } & \multirow[b]{2}{*}{ Std. dev } & \multirow[b]{2}{*}{$\begin{array}{l}\text { Std. error } \\
\text { mean }\end{array}$} & \multicolumn{2}{|c|}{$\begin{array}{l}95 \% \text { confidence interval } \\
\text { of the difference }\end{array}$} & & & \\
\hline & & & & & Lower & Upper & & & \\
\hline Pair 1 & P_1800-B_1800 & -1.00 & 2.13 & 0.62 & -2.35 & 0.35 & -1.62 & 11 & .132 \\
\hline Pair 2 & P_1800-WS_1800 & 8.92 & 3.65 & 1.05 & 6.59 & 11.24 & 8.45 & 11 & .000 \\
\hline Pair 3 & B_1800 - WS_1800 & 9.92 & 3.99 & 1.15 & 7.38 & 12.45 & 8.61 & 11 & .000 \\
\hline Pair 4 & P_1970 - B_1970 & 0.25 & 4.07 & 1.18 & -2.34 & 2.84 & 0.21 & 11 & .835 \\
\hline Pair 5 & P_1970 - WS_1970 & 10.33 & 3.92 & 1.13 & 7.85 & 12.82 & 9.14 & 11 & .000 \\
\hline Pair 6 & B_1970 -WS_1970 & 10.08 & 4.21 & 1.22 & 7.41 & 12.76 & 8.30 & 11 & .000 \\
\hline Pair 7 & P_2150 - B_2150 & 0.67 & 2.93 & 0.85 & -1.20 & 2.53 & 0.79 & 11 & .448 \\
\hline Pair 8 & P_2150 - WS_2150 & 8.50 & 3.40 & 0.98 & 6.34 & 10.66 & 8.67 & 11 & .000 \\
\hline Pair 9 & B_2150 -WS_2150 & 7.83 & 5.02 & 1.45 & 4.64 & 11.03 & 5.40 & 11 & .000 \\
\hline
\end{tabular}

tomite as the aggregate and cement contents of $250 \mathrm{~kg}$ and $300 \mathrm{~kg}$, obtaining average compressive strengths of $42 \mathrm{~kg} \mathrm{f} \mathrm{cm}^{-2}$ and $51 \mathrm{~kg} \mathrm{f} \mathrm{cm}^{-2}$, respectively. In the same study, these authors reported a thermal conductivity of $0.314 \mathrm{~W} \mathrm{~m}^{-1} \mathrm{~K}^{-1}$. This is lower by $(15,12$ and 27$) \%$ than for pumice, basalt and wood shavings, respectively.

\section{CONCLUSIONS}

This study verifies the adequateness of the material aggregation for the production of high-strength lightweight concrete blocks. Because of various concrete mixes and the use of standard techniques, it was possible to obtain a high-quality lightweight concrete mix, suitable for application in reinforced-concrete structures.

According to the results, the recommended mix determined during this project includes $1970 \mathrm{~kg}$ of pumice, with minimum and maximum values of $38 \mathrm{~kg} \mathrm{f} \mathrm{cm}^{-2}$ and $58 \mathrm{~kg} \mathrm{f} \mathrm{cm}^{-2}$, respectively, a mean value of 49.08 and a standard deviation of 7.28. It is recommended to continue the search for other natural materials and the best formulations to improve concrete blocks and production processes.

\section{Acknowledgement}

We thank Grupo Cementos de Chihuahua for the support given to this project.

\section{REFERENCES}

${ }^{1}$ Intergovernmental Panel on Climate Change (IPCC), Climate Change 2014: Mitigation of Climate Change: Working Group III Contribution to the IPCC Fifth Assessment Report, Cambridge University Press, 2014, doi:10.1017/CBO9781107415416

${ }^{2}$ Climate change 2001: synthesis report, Choice Rev. Online, 40 (2003), 40-4660-40-4660, doi:10.5860/choice.40-4660

${ }^{3}$ M. Hurlbert, J. Krishnaswarmy, E. Davin, F. Johnson, C. Mena, J. Morton, Risk management and decision making in relation to sustainable development, SRCCL - Spec. Rep. Clim. Chang. L., (2019) 235, https://www.ipcc.ch/site/assets/uploads/2019/08/2i.Chapter-7_FINAL.pdf

${ }^{4}$ S. A. Marcott, J. D. Shakun, P. U. Clark, A. C. Mix, A reconstruction of regional and global temperature for the past 11,300 years, Science, 339 (2013), 1198-1201, doi:10.1126/science.1228026

${ }^{5}$ K. L. Ebi, L. H. Ziska, G. W. Yohe, The shape of impacts to come: lessons and opportunities for adaptation from uneven increases in global and regional temperatures, Clim. Change, 139 (2016), 341-349, doi:10.1007/s10584-016-1816-9

${ }^{6}$ J. C. Lam, K. K. W. Wan, C. L. Tsang, L. Yang, Building energy efficiency in different climates, Energy Convers. Manag., 49 (2008), 2354-2366, doi:10.1016/j.enconman.2008.01.013 
${ }^{7}$ T. S. Yun, Y. J. Jeong, T. S. Han, K. S. Youm, Evaluation of thermal conductivity for thermally insulated concretes, Energy Build., 61 (2013), 125-132, doi:10.1016/j.enbuild.2013.01.043

${ }^{8}$ U.S. Energy Information Administration, U.S. energy facts explained, 2018, https://www.eia.gov/energyexplained/us-energyfacts/, (accessed October 29, 2019)

${ }^{9}$ L. R. Beltrán, R. R. Alexandri, J. R. Herrera, O. G. Ojeda, Balance Nacional de Energía, Secr. Energía, Subsecr. Planeación y Transic. Energética, (2018) 15

${ }^{10}$ International Energy Agency, Transition to Sustainable Buildings, OECD/IEA, 2013, doi:10.1787/9789264202955-en

${ }^{11}$ M. K. Dixit, C. H. Culp, J. L. Fernández-Solís, System boundary for embodied energy in buildings: A conceptual model for definition, Renew. Sustain. Energy Rev., 21 (2013), 153-164, doi:10.1016/ j.rser.2012.12.037

${ }^{12}$ D. Bansal, R. Singh, R. L. Sawhney, Effect of construction materials on embodied energy and cost of buildings - A case study of residential houses in India up to $60 \mathrm{~m} 2$ of plinth area, Energy Build., 69 (2014), 260-266, doi:10.1016/j.enbuild.2013.11.006

${ }^{13}$ H. Yoshino, T. Hong, N. Nord, IEA EBC annex 53: Total energy use in buildings-Analysis and evaluation methods, Energy Build., 152 (2017), 124-136, doi:10.1016/j.enbuild.2017.07.038

${ }^{14}$ A. Kumar, K. Kumar, N. Kaushik, S. Sharma, S. Mishra, Renewable energy in India: Current status and future potentials, Renew. Sustain. Energy Rev., 14 (2010), 2434-2442, doi:10.1016/j.rser.2010.04.003

${ }^{15}$ UNIDO, Safeguarding the environment, 2019, https://www.unido. org/our-focus/safeguarding-environment (accessed October 29, 2019)

${ }^{16}$ D. Zhou, C. Y. Zhao, Y. Tian, Review on thermal energy storage with phase change materials (PCMs) in building applications, Appl. Energy, 92 (2012), 593-605, doi:10.1016/j.apenergy.2011.08.025

${ }^{17}$ C. Barreneche, A. De Gracia, S. Serrano, M. Elena Navarro, A. M. Borreguero, A. Inés Fernández, M. Carmona, J. F. Rodriguez, L. F. Cabeza, Comparison of three different devices available in Spain to test thermal properties of building materials including phase change materials, Appl. Energy, 109 (2013), 544-552, doi:10.1016/ j.apenergy.2013.02.061

${ }^{18} \mathrm{P}$. Sukontasukkul, Use of crumb rubber to improve thermal and sound properties of pre-cast concrete panel, Constr. Build. Mater., 23 (2009), 1084-1092, doi:10.1016/j.conbuildmat.2008.05.021

${ }^{19}$ F. Pacheco-Torgal, Eco-efficient construction and building materials research under the EU Framework Programme Horizon 2020, Constr. Build. Mater., 51 (2014), 151-162, doi:10.1016/j.conbuildmat. 2013.10.058

${ }^{20}$ L. Yang, H. Yan, J. C. Lam, Thermal comfort and building energy consumption implications - A review, Appl. Energy, 115 (2014), 164-173, doi:10.1016/j.apenergy.2013.10.062

${ }^{21}$ F. M. Díez Ramírez, F. B. Muñoz, E. L. López, A. V. Polanco, Thermal evaluation of structural concretes for construction of biodigesters, Energy Build., 58 (2013), 310-318, doi:10.1016/j.enbuild. 2012.11.036

${ }^{22}$ C. K. Y. Leung, Concrete as a Building Material, Encycl. Mater. Sci. Technol., (2001), 1471-1479, doi:10.1016/B0-08-043152-6/00267-9

${ }^{23}$ F. Pelisser, A. Barcelos, D. Santos, M. Peterson, A. M. Bernardin, Lightweight concrete production with low Portland cement consumption, J. Clean. Prod., 23 (2012), 68-74, doi:10.1016/ j.jclepro.2011.10.010

${ }^{24}$ M. Bachar, L. Azzouz, M. Rabehi, B. Mezghiche, Characterization of a stabilized earth concrete and the effect of incorporation of aggregates of cork on its thermo-mechanical properties: Experimental study and modeling, Constr. Build. Mater., 74 (2015), 259-267, doi:10.1016/j.conbuildmat.2014.09.106

${ }^{25}$ N. A. Tregger, M. E. Pakula, S. P. Shah, Influence of clays on the rheology of cement pastes, Cem. Concr. Res., 40 (2010), 384-391, doi:10.1016/j.cemconres.2009.11.001
${ }^{26}$ I. Cinina, E. Zile, O. Zile, Mechanical behavior of concrete columns confined by basalt FRP windings, Mech. Compos. Mater., 48 (2012), 539-546, doi:10.1007/s11029-012-9298-y

${ }^{27} \mathrm{~W}$. Li, J. Xu, Mechanical properties of basalt fiber reinforced geopolymeric concrete under impact loading, Mater. Sci. Eng. A., 505 (2009), 178-186, doi:10.1016/j.msea.2008.11.063

${ }^{28}$ M. Bederina, B. Laidoudi, A. Goullieux, M. M. Khenfer, A. Bali, M. Quéneudec, Effect of the treatment of wood shavings on the physico-mechanical characteristics of wood sand concretes, Constr. Build. Mater., 23 (2009), 1311-1315, doi:10.1016/j.conbuildmat. 2008.07.029

${ }^{29}$ D. K. Rajak, P. G. Deshpande, L. A. Kumaraswamidhas, Experimental analysis of energy absorption behaviour of Al-tube filled with pumice lightweight concrete under axial loading condition, IOP Conf. Ser. Mater. Sci. Eng., 225 (2017) 1, 012032, doi:10.1088/ 1757-899x/225/1/012032

${ }^{30}$ Organismo Nacional de Normalización y Certificación de la Construcción y Edificación S.C., Norma: NMX-C-404-ONNCCE, Industria de la construcción - Bloques, ladrillos o tabiques, tabicones para uso no estructural - Especificaciones - Método de prueba, Fichas Técnicas, 2005, https://www.onncce.org.mx/es/?option=com_ merchant $\&$ view=category $\&$ cid=9 (accessed March 8, 2013)

${ }^{31}$ Organismo Nacional de Normalización y Certificación de la Construcción y Edificación S.C., NMX-C-441-ONNCCE, Industria de la construcción - Bloques, ladrillos o tabiques, tabicones para uso no estructural - Especificaciones, Fichas Técnicas, 2005, http://www.dof.gob.mx/nota_detalle.php?codigo $=5267404 \&$ fecha $=1$ 0/09/2012 (accessed March 8, 2013)

${ }^{32}$ Organismo Nacional de Normalización y Certificación de la Construcción y Edificación S.C., Norma: NMX-C-038-ONNCCE2013 - Industria de la construcción - Mampostería - Determinación de las dimensiones de bloques, tabiques o ladrillos y tabicones Método de ensayo, Fichas Técnicas, 2014, https://www.onncce. org.mx/es/venta-normas/fichas-tecnicas?view=item\&id=1732 (accessed March 8, 2013)

${ }^{33}$ Organismo Nacional de Normalización y Certificación de la Construcción y Edificación S.C., Norma: NMX-C-036ONNCCE-2013 - Industria de la Construcción - Mampostería Resistencia a la compresión de bloques, tabiques o ladrillos y tabicones y adoquines - Método de Ensayo, Fichas Técnicas, 2004, https://www.onncce.org.mx/es/venta-normas/fichas-tecnicas?view=it em\&id=1730 (accessed March 8, 2013)

${ }^{34}$ M. D. A. Thomas, K. J. Folliard, Concrete aggregates and the durability of concrete, Durab. Concr. Cem. Compos., Elsevier Ltd., (2007), 247-281, doi:10.1533/9781845693398.247

${ }^{35} \mathrm{M}$. Yilmaz, A. Turul, The effects of different sandstone aggregates on concrete strength, Constr. Build. Mater., 35 (2012), 294-303, doi:10.1016/j.conbuildmat.2012.04.014

${ }^{36}$ ASTM, C 31, C 39, C 617, C 1077, C 1231, Annu. B. ASTM Stand., (2006), 04.02. www.astm.org (accessed March 17, 2013)

${ }^{37}$ Diario Oficial de la Federación, NOM-008-ENER-2001, Eficiencia enérgetica en edificaciones, envolvente de edificios no residenciales, Secr. Energía, 2 (2001) 26

${ }^{38}$ IBM, SPSS Statistics, 2017, https://www.ibm.com/mx-es/products/ spss-statistics

${ }^{39} \mathrm{~L}$. Gündüz, The effects of pumice aggregate/cement ratios on the low-strength concrete properties, Constr. Build. Mater., 22 (2008), 721-728, doi:10.1016/j.conbuildmat.2007.01.030

${ }^{40}$ D. K. Panesar, B. Shindman, The mechanical, transport and thermal properties of mortar and concrete containing waste cork, Cem. Concr. Compos., 34 (2012), 982-992, doi:10.1016/j.cemconcomp. 2012.06.003

${ }^{41}$ O. Ünal, T. Uygunoglu, A. Yildiz, Investigation of properties of low-strength lightweight concrete for thermal insulation, Build. Environ., 42 (2007), 584-590, doi:10.1016/j.buildenv.2005.09.024 